\title{
ランチョンセミナー(8) 側頭骨の画像診断
}

\author{
司会のことば \\ 小川 郁 \\ 慶應義塾大学 耳鼻咽喉科
}

側頭骨は耳管から鼓室、乳突洞、乳突蜂巣という外界から連続する複雑で個人差の大きい含気腔とその中の巧妙に構 成された耳小骨を中心とする伝音機構、さらには最も緻密で微細な感覚器である螖牛と前庭とを含有する内耳骨包から なる。また、側頭骨内にはこれらに加えて顔面神経およびその分枝が複雑に走行するなど、体内で最も複雑な骨組織で あることは間違いない。このような側頭骨に生じる側頭骨疾患はこれらの構造に関連する多彩な症状を呈し、その診断 に際しては、はじめに聴覚検査、前庭機能検査、顔面神経機能検査などの機能検査を行うが、治療方針を決定するため には画像検査が不可欠である。近年の画像検査法の進歩はめざましく、特に MRI を主体とする軟部組織の画像診断の 精度は格段に向上しているが、複雑な骨組織に生じる側頭骨疾患の診断への応用には一定の限界がある。一方、CTは 側頭骨疾患の診断の主役を担っており、コーンビーム CT な゙の新しい検査法によってその解像度も飛躍的に向上して いるが、MRIに反して軟部組織の情報は少なくなるなど、各検査法の適応と限界とを理解する必要がある。このよj に側頭骨の画像診断では対象となる側頭骨疾患の病態を理解し、適切に画像検査法を選択、画像診断を進めることが最 も重要となる。

今回、本ランチョンセミナーでは膨大な側頭骨疾患の診断と治療との経験を有する内藤 泰先生に「側頭骨の画像診 断」と題して CT、MRI の画像検査法の基本知識から、各疾患の病態に則した CT、MRI の選択法、小児から成人まで の成長による画像所見の変化、外耳道、耳小骨、内耳、内耳道の先天奇形、中耳真珠腫を中心とする感染・炎症・代謝 性疾患、側頭骨骨折などの外傷性疾患、聴神経腫瘍などの腫瘍性疾患まで、側頭骨の画像診断についてのエッセンスに ついて網羅的にご講演いただく予定である。内藤先生が結語で述べられているように側頭骨の画像診断に際してはまず 側頭骨疾患の病態および基本的所見を理解するとともに、臨床上で遭遇した希少例について詳細な検討を行い、正確な 診断を行う経験を積むことが最も重要である。これから側頭骨の画像検査を学ぼうとする若手耳鼻咽喉科医にとっての 画像診断力向上のための心構えから、ベテラン耳鼻咽喉科医にとっての明日からの日常診療に役立つ情報まで、すべて の耳鼻咽喉科医にとって非常に有益なご講演を帱聴できるものと期待している。 


\title{
側頭骨の画像診断
}

\author{
内藤 泰 \\ 神戸市立医療センター中央市民病院
}

はじめに

一般の画像診断書などでは画像による疾患診断までは示されるが、それに対する実際の治療法や治療結果には言及さ れることはまれである。しかし、個々の疾患には、それぞれの病因、診断、治療、予後という一連の流れがあり、その 診断までを見ただけで全体像を把握することは難しい。臨床的に適切な画像診断を行うためには、治療の観点が不可欠 である。本セミナーでは、側頭骨画像診断の要点を治療の観点も含めて解説する。

\section{画像検査の基本知識}

側頭骨画像診断の主流である CT と MRI は体組織の放射線吸収度や磁気共鳴信号強度という数值デー夕を断面画像 に再構成したもので、日常的な診断画像の観察には特別な知識を必要としないが、微妙な所見についての臨床的判断に は、その所見が現実の病態を表しているのか、画像構成上の限界や種々のデジタル処理上のアーティファクトなのかを 考えなければならない場合がある。このセミナーでは CT 画像の解像度、ウインドウ幅とウィンドウレベルの意味、輪 郭強調画像処理などの画像の原理だけでなく、放射線被曝についても解説し、MR 画像では炎症、腫瘍、血腫、種々の 性状の液体などの見え方と、画像解釈上の注意点について基本事項をまとめる。

\section{CT と MRI の選択}

側頭骨の画像診断で観察する対象のうち、外耳道と中耳は主に骨性の構造が問題となるので、まず CTを選択する。 一方、内耳と内耳道を観察しなければならない病態は先天奇形、内耳炎、腫瘍、神経の低形成や萎縮などであり、骨性 の杵組みは CT、内耳や内耳道内の軟組織の観察には MRI が適している。炎症や腫瘍を疑う場合には単純 MRIに加え て造影 MRI 検查も行うべきである。大まかに言えば、(例外はあるが)外耳道と中耳疾患には CT、内耳道疾患には MRI が第一選択のモダリティで、内耳疾患では両者が必要ということになる。

\section{小児の正常画像：成長による変化}

通常、小児画像は成人の正常解剖を念頭に置いて読影するが、特に、乳幼児の側頭骨では各部の大きさや、その相互 比率が成人とは異なるため、読影や所見の解釈に注意を要する。内耳（迷路骨胞）と耳小骨は生下時から成人まで画像 上の大きさに変化は見られないが、内耳道は年齢とともに長さが長くなり、前庭水管も乳突部の発育に伴って外側後方 に延長して行く。外耳道も生後、著明に成長する。最近は人工内耳手術のため、1歳代でこのあたりの手術を行う必要 が生じて抢り、外耳道のように成人と大きくサイズや形態が異なり、顔面神経走行とも密接に関連する部位については 低年齢小児の構造を十分に理解しておくことが重要である。乳突蜂巣も年齢とともに拡大するが、幼少時の中耳炎反復 罹患があると蜂巣発育が抑制されるのは広く知られるところである。前庭水管の先天的拡大の遺伝子変異との関係や難 聴の進行は良く調べられているが、逆に前庭水管が低形成の例も見られ、将来のメニエール病発症との関連が注目され る。

先天奇形 : 外耳道 $\cdot$ 耳小骨 $\cdot$ 内耳 $\cdot$ 内耳道

外耳道の先天奇形では主に閉鎖と狭窄が問題になり、外耳道真珠腫形成の有無についても注意を要する。耳小骨奇形 は、外耳道奇形に合併する例と、単独で生じる例がある。耳小骨奇形の分類は種々の方法が報告されているが、発生学 的見地から 3 群に分けた船坂分類と、個々の異常を点数化し、奇形の総合的状況を点数化したJahrsdoerferのスコアな どが実用上役立つ。

内耳奇形の分類は CT 画像所見に基づき、内耳発生のいろいろな段階での発育停止の観点から分類を行った Sennaroglu・Saatci の分類が現在の標準である。この分類は多岐にわたるが、実地臨床上の頻度から言うと、common cavity、 incomplete partition type-I(IP-I)、incomplete partition type-II(IP-II) の3つをしっかり理解すれば多くの症例で診断 ができる。症候群性の難聴では、多様な形態異常の観察が奇形全般の診断にも役立つ CHARGE 症候群をとりあげる。

内耳道奇形の診断は人工内耳の効果を予測するうえで極めて重要である。蝸牛軸基底部と内耳道をつなぐ蝸牛神経管 は従来あまり注目されていなかったが、近年は人工内耳手術の術側決定や、1 側性難聴の病因として、側頭骨 CT 上、 必須のチェックポイントとなっている。また、高分解能 MRIによる内耳道内の神経、特に蝸牛神経と第 8 脳神経の観 察は難聴の診断と治療方針決定に役立つ。

感染・炎症・代謝

例えば通常の急性中耳炎では傾骨 CT などの高度の画像検査は不要であるが、合併症を伴う急性中耳炎や慢性中耳 炎、中耳真珠腫では、乳突蜂巣発育や耳小骨連鎖の病態観察、手術の要否などの治療方針決定のために画像診断が必要 になる。手術例では、術後の経過観察にも画像診断が大きな役割を果たす。また、難聴病態の観点からみると、一般に 
伝音難聴では側頭骨 CT を選択して耳小骨連鎖と中耳腔の状態を観察することが基本であり、急性あるいは亜急性に進 行する感音難聴では内耳・内耳道の炎症や腫瘍を念頭において単純および造影 MRI 検査を選択する。

このセミナーでは、基本事項として中耳真珠腫をとりあげて、術前および術後のチェックポイントを、最近話題のnon一 EP 拡散強調 MRI も含めて解説する。応用編としては、錐体尖病変、S 状静脈洞血栓症、内耳・内耳道の炎症疾患、特 発性脳春髄液減少症などをとりあげる予定である。

外傷

当院は救急病院で、多様な頭部外傷患者の診療を行っている。ここでは、側頭骨骨折について、軽微なものと重症例 を呈示し、難聴、顔面神経麻痺、前庭機能異常、外傷性髄液漏の対処などと、手術治療の結果も含めて呈示する。

腫瘍

側頭骨領域の腫瘍で日常臨床上最も頻繁に遭遇するのは聴神経腫瘍である。内耳道内に限局する小腫瘍では画像によ る経過観察を行う例が多く、特に腫瘍の占拠部位が内耳道底に至っていない場合、相対的に良好な聴力が保たれること が多い。一度、造影 MRI を含めて確定診断を行った後は、基本的に造影なしの高分解能 MRI で十分経過を追うことが できる。

頻度は低いが、外耳道・中耳癌は治療の観点から早期診断が重要で、頭蓋内も含めた周囲臓器への進展診断、FDGPETによる代謝活性の評価が治療方針決定の決め手になる。そのほか、グロムス腫瘍、顔面神経鞘腫などの良性腫瘍 についても、治療前後の所見を示して着眼点を解説する。

\section{結語}

側頭骨は狭い領域に微細で機能的に重要な構造が密集しており、わずかな所見の違いが大きな症状の違いに対応する ことが少なくない。対象となる病態も先天奇形から感染・炎症、外傷、腫瘍など多岐にわたり、その中で、画像診断は 正確な診断、治療予後予測、治療効果の評価と経過観察に重要な役割をはたす。まず一般的疾患の基本所見を理解する とともに、臨床上で遭遇した希少例について、その都度、成書や文献などで十分調べて正確な診断を行う経験を積み重 ねることが診断力向上につながる。 